\title{
Environmental assessment of different vehicle technologies and fuels
}

\author{
F. Boureima ${ }^{1}$, M. Messagie ${ }^{1}$, N. Sergeant ${ }^{1}$, J. Matheys ${ }^{1}$, \\ J. Van Mierlo ${ }^{1}$, M. De $\operatorname{Vos}^{2}$, B. De Caevel ${ }^{2}$, L. Turcksin ${ }^{1}$ \\ \& C. Macharis ${ }^{1}$ \\ ${ }^{1}$ Mobi Research Group, Vrije Universiteit, The Netherlands \\ ${ }^{2}$ RDC-Environment, Brussels, Belgium
}

\begin{abstract}
In this paper, a comparative LCA of conventional and alternative vehicles is performed. Thanks to a modeling approach combining LCA methodology, vehicle homologation data and statistical tools, all the available vehicle types in a given fleet are included in a single LCA model. Statistical distributions are used to include the variations of the main parameters (weight, fuel consumption and emissions) of all the considered vehicles in the LCA model. When dealing with greenhouse effect, battery electric vehicles (BEV) powered with the Belgian electricity supply mix, have a lower greenhouse effect (18.6 ton $\mathrm{CO}_{2}$ eq/lifetime) than all the comparable vehicle technologies with exception of the sugar cane based bio-ethanol $\mathrm{E} 85$ vehicle (8.47 ton $\mathrm{CO}_{2}$ eq/lifetime). For the different impact categories considered in this study, the impacts of the LPG technology are comparable to diesel. Euro $4 \mathrm{LPG}$ and Euro 4 diesel have respectively greenhouse effects of 53.2 ton $\mathrm{CO} 2 \mathrm{eq} /$ lifetime and 49.4 ton $\mathrm{CO}_{2}$ eq/lifetime. FCEVs have lower impact than petrol and diesel vehicles for greenhouse effect, respiratory effect and acidification. CNG vehicles appear to be an interesting alternative for conventional vehicles. They have a low greenhouse effect (34.7 ton $\mathrm{CO}_{2}$ eq/lifetime for a Euro $5 \mathrm{CNG}$ ) and the best score for respiratory effects and acidification. Furthermore Euro $4 \mathrm{CNG}$ and Euro $4 \mathrm{HEV}$ have comparable greenhouse effects (respectively 44.9 ton $\mathrm{CO}_{2}$ eq/lifetime and 46.4 ton $\mathrm{CO}_{2}$ eq/lifetime). Thanks to an iterative calculation process and the use of range of values instead average values, the variation of all the LCA results is assessed without performing a new LCA model. This approach provides the
\end{abstract}


decision makers with a detailed environmental picture of a fleet allowing them to take the right measure for right group of vehicles

Keywords: range-based LCA, fuel/technology, segment, alternative vehicle.

\section{Introduction}

In vehicle LCA studies, results are usually produced for an average national situation of conventional cars. However, the LCA results of a vehicle can vary according to parameters such as the segment (related to the size and the intended use of a vehicle), the technology (internal combustion engine, hybrid, battery electric, fuel cell electric...) and the type of fuel (petrol, diesel, natural gas...). For some specific impact categories, even the Euro emission standard can make a difference between vehicles of the same segment and technology. However, producing LCA results for all the types of vehicles of a national fleet is a challenging task. In this paper, a global approach including all available vehicle types in a national fleet has been developed. This approach allows including all vehicle technologies and fuels with respect to their segments and emission standards in a single LCA model.

\section{Vehicle segments in Belgium}

The definition of the segmentation parameters of a fleet is a critical issue. Parameters such as the engine displacement (FCAI [1]), the vehicle length (EURONCAP [2]) or a combination of several parameters (FISITA [3]) are generally used for fleet segmentation. In the specific case of Belgium, a classification based on the Ecoscore approach and on the FEDERAUTO (The Belgian confederation of car traders and mechanics) approach (Reniers [4]) has been set up, combining the weight and the length of the vehicles. In this paper, the fleet has been divided into different vehicle segments according to the specific context of the Belgian market (Table 1).

Table 1: Vehicle segmentation in Belgium.

\begin{tabular}{|c|c|}
\hline Segments & Examples \\
\hline superminis & Citroen C1, Peugeot 106, Smart FORTWO \\
\hline city cars & Fiat Punto \\
\hline small family cars & Ford Focus, Opel Astra, Honda Civic \\
\hline family cars & Volvo V50, Toyota PRIUS, \\
\hline small monovolumes & Ford Focus C-MAX, Opel Zafira, \\
\hline monovolumes & Ford Galaxy, Peugeot 807 \\
\hline exclusive cars & Mercedes S-KLASSE, Lexus LS \\
\hline sport cars & Porsche 911 \\
\hline SUV & Lexus RX, Mercedes M KLASSE \\
\hline
\end{tabular}




\section{Methodology}

Within this study, an LCA methodology with per-model applicability instead of an average vehicle LCA has been developed. This methodology allows taking into account all the segments of a car market and producing LCA results per vehicle segment, technology and Euro emission standard (Figure 1).

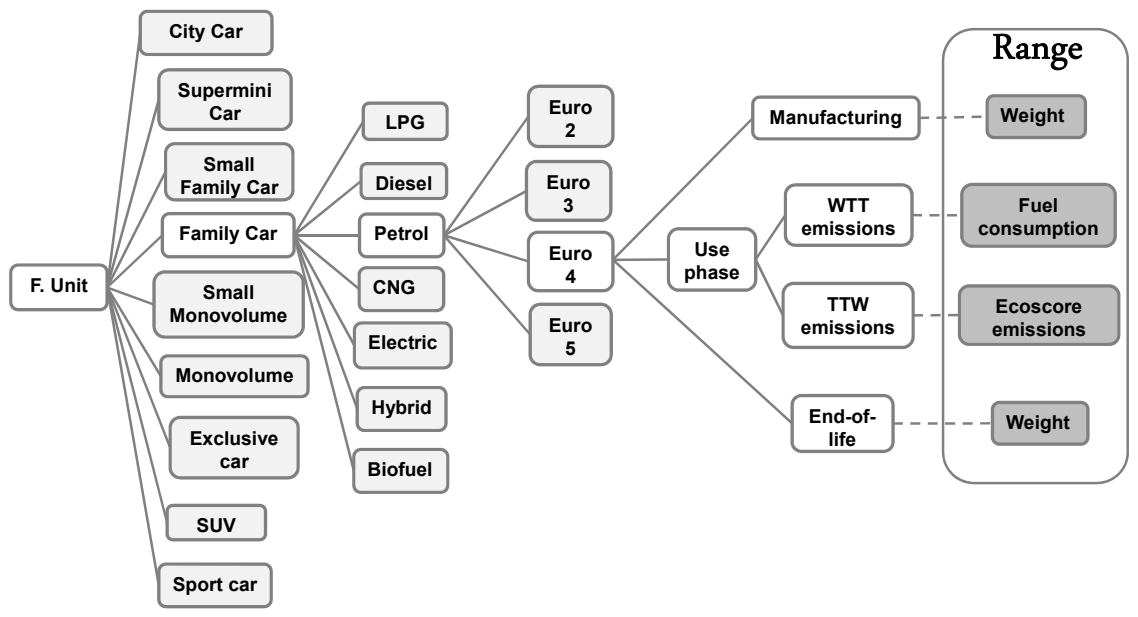

Figure 1: $\quad$ Vehicle LCA model [5].

\subsection{Goal and scope}

This study aims at analysing the life cycle impact of all the registered family cars in Belgium on one hand and assessing the influence of vehicle parameters on its LCA results on the other hand. The assessment describes the current situation of the Belgian fleet. Whenever possible, the most recent data have been used. They are completed with European data when specific data for Belgium are not available. The raw material production, transport, manufacturing, use, maintenance and end-of-life of all the vehicles are taken into account. The road infrastructures, the refuelling stations and the electrical charging infrastructures as well as services such as insurance are not included in the scope of this study.

\subsection{The functional unit (FU)}

The functional unit of this LCA has been defined as the use of a passenger car in Belgium over a life time driven distance of $230500 \mathrm{~km}$ corresponding to a vehicle lifespan of 13.7 years (FEBELAUTO [6]; FPS Economy [7]). However, the possible shorter or longer lifetime driven distances are taken into account in order to assess the variation of the contribution of the manufacturing phase to the overall impact according to the lifetime driven distance. 


\section{Inventory}

\subsection{Manufacturing and maintenance}

The LCI data of the 'Golf A4, 1,41 Otto' (Schweimer and Levin [8]) used in the ecoinvent database (Spielmann et al. [9]) has been adapted to model the manufacturing phase of all the internal combustion engine (ICE) vehicles with respect to their specific weights. As for the manufacturing phase, a maintenance pack has been modelled (Table 4) with assumptions from reference (Nemry et al. [10]) and used as a parameter to model the maintenance of all the other vehicles. For alternative vehicles such as BEV and FCEV, the LCI of the Golf A4 has been used to model only the body shell. Inventory data of specific parts of these cars such as hydrogen tanks (Table 2) and fuel cells (Table 3) of the FCEV have been gathered from (Kudoh et al. [11]) and adapted to the individual situation of the FCEV. The detailed material breakdowns of the different battery technology as well the manufacturing energy consumptions are included in the inventory (Matheys et al. [12]). However, this information is under confidentiality agreements and could not be revealed in this paper.

Table 2: $\quad$ Adapted manufacturing data of the hydrogen tank of the FCEV.

\begin{tabular}{|c|c|c|}
\hline Inputs & & Units \\
\hline polyethylene & 15 & $\mathrm{~kg}$ \\
\hline carbon fibre & 71.4 & $\mathrm{~kg}$ \\
\hline epoxy resin & 30.6 & $\mathrm{~kg}$ \\
\hline aluminum & 6 & $\mathrm{~kg}$ \\
\hline stainless steel & 9 & $\mathrm{~kg}$ \\
\hline electricity & 4.5 & $\mathrm{kWh}$ \\
\hline
\end{tabular}

Table 3: $\quad$ Adapted manufacturing data of the fuel cell of the FCEV.

\begin{tabular}{|c|c|c|}
\hline Inputs & Amount & Units \\
\hline trichloromethane & 1.92 & $\mathrm{~kg}$ \\
\hline hydrogen fluoride & 0.65 & $\mathrm{~kg}$ \\
\hline oxygen & 0.09 & $\mathrm{~kg}$ \\
\hline white fuming nitric acid & 0.22 & $\mathrm{~kg}$ \\
\hline platinum & 0.09 & $\mathrm{~kg}$ \\
\hline carbon black & 0.09 & $\mathrm{~kg}$ \\
\hline hydrogen chloride & 0.29 & $\mathrm{~kg}$ \\
\hline nitric acid & 0.05 & $\mathrm{~kg}$ \\
\hline ammonia & 0.02 & $\mathrm{~kg}$ \\
\hline carbon fiber & 10.87 & $\mathrm{~kg}$ \\
\hline oil cokes & 26.14 & $\mathrm{~kg}$ \\
\hline oil pitch & 10.56 & $\mathrm{~kg}$ \\
\hline formaldehyde resin & 7.12 & $\mathrm{~kg}$ \\
\hline silicone rubber & 1.81 & $\mathrm{~kg}$ \\
\hline steel & 16.17 & $\mathrm{~kg}$ \\
\hline naphtha & 13.10 & $\mathrm{~kg}$ \\
\hline electricity & 2338.60 & $\mathrm{kWh}$ \\
\hline steam & 182.23 & $\mathrm{~kg}$ \\
\hline fuel oil & 2.73 & $\mathrm{~kg}$ \\
\hline
\end{tabular}


Table 4: $\quad$ Vehicle maintenance pack.

\begin{tabular}{|c|c|}
\hline & Amount \\
\hline tires & $165.96 \mathrm{~kg}$ \\
\hline oil & $67.61 \mathrm{~kg}$ \\
\hline washing water & $12.29 \mathrm{~m} 3$ \\
\hline
\end{tabular}

\subsection{Use phase}

The use phase of the vehicles is split up into Well-to-Tank (WTT) and Tank-toWheel (TTW). The WTT part covers the production and the distribution of the fuel while the TTW phase covers the use of this fuel by the vehicle. WTT data concerning petrol, diesel, natural gas, B100 (100\% bio-diesel) and E85 (85\% ethanol and 15\% petrol) are gathered from the Ecoinvent database (Table 5). The Belgian electricity supply mix, as well as specific electricity production pathways (coal, oil, hydro, nuclear, natural gas) are derived from the ecoinvent database and are applied for different use scenarios of BEV (Table 6). Liquefied Petroleum Gas (LPG) is modeled with unit processes from ecoinvent (propane/butane combined with liquefaction process) on the basis of assumptions made in the reference (EUCAR/CONCAWE/JRC [13]). The hydrogen used for the FCEV is produced by steam reforming of natural gas and is modelled with inputs from the Roads2hycom project (Prieur et al. [14]) (Table 5).

Table 5: WTT $\mathrm{CO}_{2}$ emissions of fossil and renewable fuels (Frischknecht and Rebitzer [15]).

\begin{tabular}{|c|c|c|c|c|c|c|c|c|}
\hline & Petrol & Diesel & CNG & $\begin{array}{c}\text { E85 } \\
\text { (S.cane) }\end{array}$ & $\begin{array}{c}\text { E85 } \\
\text { (S.beets) }\end{array}$ & $\begin{array}{c}\text { RME } \\
\text { (B 100) }\end{array}$ & LPG & $\begin{array}{c}\mathbf{H}_{2} \\
\text { (SMR) }\end{array}$ \\
\hline $\begin{array}{c}\text { WTT } \\
\mathbf{C O}_{\mathbf{2}} \text { (kg/GJ) }\end{array}$ & 15.67 & 11.02 & 3.21 & -67.3 & -40.12 & -39.99 & 14.52 & 88.33 \\
\hline
\end{tabular}

Table 6: WTT $\mathrm{CO}_{2}$ emissions of different electricity production pathways (Frischknecht and Rebitzer [15]).

\begin{tabular}{|c|c|c|c|c|c|c|}
\hline & $\begin{array}{c}\text { Belgian } \\
\text { mix }\end{array}$ & $\begin{array}{c}\text { Hydro } \\
\text { electricity }\end{array}$ & $\begin{array}{c}\text { Nuclear } \\
\text { electricity }\end{array}$ & $\begin{array}{c}\text { Natural gas } \\
\text { electricity }\end{array}$ & $\begin{array}{c}\text { Oil } \\
\text { electricity }\end{array}$ & $\begin{array}{c}\text { Coal } \\
\text { electricity }\end{array}$ \\
\hline $\begin{array}{c}\mathbf{W T T} \\
\mathbf{C O}\end{array}$ & $3.70 \mathrm{E}-$ & & & & & \\
$\mathbf{( k g / k W h}$ & 01 & $3.36 \mathrm{E}-03$ & $7.37 \mathrm{E}-03$ & $5.45 \mathrm{E}-01$ & $9.40 \mathrm{E}-01$ & $1.09 \mathrm{E}+00$ \\
\hline
\end{tabular}

At the TTW side, the major part of the data is from the Ecoscore database (Table 8). Close to the $\mathrm{CO}_{2}$ emissions, other pollutants such as NOx, SOx, PM, $\mathrm{CO}, \mathrm{VOC} \ldots$ are also taken into account. In the specific case of E85 and B100 vehicles, the TTW emissions and fuel consumption have been gathered from the BIOSES project (Turcksin et al. [16]). The fuel consumption and the emissions are measured according to the New European Driving Cycle (NEDC).

For BEVs, the ratio between the life time driven distance and the cycle life of the lithium-ion battery (Table 7) has been used to calculate the number of the needed batteries for the BEV. 
Table 7: $\quad$ Specifications of the batteries of the BEVs.

\begin{tabular}{|c|c|c|c|c|}
\hline & Tesla Roadster & Mitsubishi iMiev & Nissan leaf & units \\
\hline Capacity & 56 & 16 & 24 & $\mathrm{kWh}$ \\
\hline Energy density & 121 & 80 & 80 & $\mathrm{Wh} / \mathrm{kg}$ \\
\hline Weight & 450 & 200 & 300 & $\mathrm{~kg}$ \\
\hline
\end{tabular}

In the case of the FCEV, a lifespan of 5000 driving hours (Fuel Cell and Hydrogen-Joint Undertaking project [17]) has been considered for the fuel cell. As a consequence, only one fuel cell stack is considered for the FCEV.

Table 8: $\quad$ Specifications of different family car technologies (Timmermans et al. [18]).

\begin{tabular}{|c|c|c|c|c|}
\hline & Weight (tonne) & & Units & TTW $\mathrm{CO}_{2}(\mathrm{~g} / \mathrm{km})$ \\
\hline $\begin{array}{c}\text { Petrol } \\
\text { (Euro 4) }\end{array}$ & $\begin{array}{c}{ }^{\mathrm{I}} \mathrm{T} \\
(0.88,1.23,2.44)\end{array}$ & $\mathrm{T}(5.60,7.10,13.70)$ & $1 / 100 \mathrm{~km}$ & $\mathrm{~T}(129.82,170.80,334.31)$ \\
\hline $\begin{array}{c}\text { Petrol } \\
\text { (Euro 5) }\end{array}$ & $\mathrm{T}(1.3,1.48,1.92)$ & $\mathrm{T}(7.10,7.20,11.90)$ & $1 / 100 \mathrm{~km}$ & $\mathrm{~T}(161.70,167.35,290.84)$ \\
\hline $\begin{array}{c}\text { LPG } \\
\text { (Euro 4) }\end{array}$ & $\mathrm{T}(1.28,1.53,1.69)$ & $\mathrm{T}(9.50,13 \cdot 10,13.60)$ & $1 / 100 \mathrm{~km}$ & $\begin{array}{c}\mathrm{T}(155.38, \\
218.38,227.78)\end{array}$ \\
\hline $\begin{array}{c}\text { Diesel } \\
\text { (Euro 4) }\end{array}$ & $\mathrm{T}(1.01,1.35,2.29)$ & $\mathrm{T}(4.30,5.30,9.30)$ & $1 / 100 \mathrm{~km}$ & $\begin{array}{c}\mathrm{T}(110.46,139.09, \\
255.80)\end{array}$ \\
\hline $\begin{array}{c}\text { Diesel } \\
\text { (Euro 5) }\end{array}$ & $\mathrm{T}(1.2,1.52,1.88)$ & $\mathrm{T}(4.50,5.90,7.20)$ & $1 / 100 \mathrm{~km}$ & $\begin{array}{c}\mathrm{T}(116.24 \\
155.23,192.85)\end{array}$ \\
\hline $\begin{array}{c}\text { E85 } \\
\text { (S.cane) }\end{array}$ & 1.3 & 12.16 & $1 / 100 \mathrm{~km}$ & $\begin{array}{c}\mathrm{T}(194.61,192.68,191, \\
41)\end{array}$ \\
\hline $\begin{array}{c}\text { E85 } \\
\text { (S.beets) }\end{array}$ & 1.3 & 12.16 & $1 / 100 \mathrm{~km}$ & $\begin{array}{c}\mathrm{T}(194.61,192.68,191, \\
41)\end{array}$ \\
\hline $\begin{array}{l}\text { B100 } \\
\text { (RME) }\end{array}$ & 1.26 & 6.07 & $1 / 100 \mathrm{~km}$ & $\begin{array}{c}\mathrm{T}(149.54, \\
149.65,149.94)\end{array}$ \\
\hline $\begin{array}{l}\text { Hybrid } \\
\text { (Euro 4) }\end{array}$ & $\mathrm{T}(1.26,1.62,1.94)$ & $\mathrm{T}(4.30,6.10,7.90)$ & $1 / 100 \mathrm{~km}$ & $\begin{array}{c}\mathrm{T}(102.18,145.22 \\
187.19)\end{array}$ \\
\hline $\begin{array}{c}\text { CNG } \\
\text { (Euro 4) }\end{array}$ & 1.47 & 9.00 & $\begin{array}{c}\mathrm{m} 3 / 100 \\
\mathrm{~km}\end{array}$ & $\begin{array}{c}\mathrm{T}(161.00,161.00, \\
161.00)\end{array}$ \\
\hline $\begin{array}{c}\text { CNG } \\
\text { (Euro 5) }\end{array}$ & 1.58 & 6.80 & $\begin{array}{c}\mathrm{m} 3 / 100 \\
\mathrm{~km}\end{array}$ & 121.00 \\
\hline FCEV & 1.63 & 0.1 (60 miles/kg) & $\mathrm{kg} / \mathrm{km}$ & 0 \\
\hline $\begin{array}{c}\text { BEV } \\
\text { (iMiev) }\end{array}$ & 1.08 & 0.135 & $\mathrm{kWh} / \mathrm{km}$ & 0 \\
\hline $\begin{array}{l}\text { BEV(Nissan } \\
\text { Leaf) }\end{array}$ & 1.54 & 0.173 & $\mathrm{kWh} / \mathrm{km}$ & 0 \\
\hline $\begin{array}{l}\text { BEV } \\
\text { (Tesla) }\end{array}$ & 1.24 & 0.17 & $\mathrm{kWh} / \mathrm{km}$ & 0 \\
\hline
\end{tabular}

${ }^{1} \mathrm{~T}$ stands for triangular distribution.

\subsection{End-of-life phase}

An end-of-life scenario including the transport to the recycling plant, depollution, shredding and the sorting has been defined in this study. Specific rates of material and energy recovery per type of material which were collected in the framework of the OVAM survey on Belgian recycling plants are used 
(OVAM [19]). In this paper, the so called "IISI Appendix 5" equation (1) developed by the International Iron and Steel Institute (IISI [20]) has been used to model the recycling credit of the End-of-Life phase of the different vehicles.

- Single recycling cycle equation:

$$
X=X_{\text {primary }}+\left(X_{\text {recycled }}-X_{\text {primary }}\right) * R R * Y
$$

where

$X$ : LCI data with recycling credit;

Xprimary: $\mathrm{X}$ in the case of production based on $100 \%$ virgin material; Xrecycled: $\mathrm{X}$ in the case of production based on 100\% recycled scrap; $R R$ : Recovery Rate (Total weight of recovered scrap/Weight delivered) $<1$; $Y$ : Yield (Useful recycled product/Input of scrap as raw material) $<1$.

\section{Impact calculation}

In the framework of this paper three impact categories have been assessed: greenhouse effect (IPCC [21]), acidification (Guinée et al. [22]) and respiratory effects (Jolliet et al. [23]). The LCA results are calculated for all the types of registered vehicles in Belgium. An iterating impact calculation approach has allowed repeating 1000 times the operation for each impact category with different values chosen at random between the minimum and the maximum for the parameters (weight, fuel and electricity consumption, emissions) modelled with a distribution function. However, it is important to keep in mind that this study does not include the amounts but only the types of vehicle within the fleet.

\section{Results}

The comparison of different family car technologies shows that the climate impact is highly influenced by the vehicle technology, the type of fuel and the type of feedstock used to produce the fuel (figure 2). One can notice in figure 2 that the sugar cane based E85 vehicle has the lowest greenhouse effect. This is due essentially to the benefit of the $\mathrm{CO}_{2}$ uptake from the air during the production of the sugar cane. Additionally, the electricity used in the sugar cane fermentation plant is produced with the bagasse obtained after the crushing of the sugar cane. However this good score of the E85 vehicle highly depends on the feedstock type and e.g. shifting from sugar cane to sugar beets will increase by more than three times the impact of the E85 vehicle (figure 2). After the sugar cane based E85 vehicle, the BEV using the Belgian supply mix electricity has the lowest greenhouse effect. This can be explained by the fact more than $55 \%$ of the Belgian electricity is nuclear and the fact that BEV is an exhaust emission free vehicle. Despite the low greenhouse effect of the BEV, the contribution of the lithium ion battery to the overall impact is still higher but it is finally balanced by the benefit of the recycling. The FCEV which is also an exhaust emission free vehicle has a greenhouse effect which is higher than the BEV and 
comparable to the B100 (RME) one (Figure 2). The difference between the FCEV and the BEV is due essentially to the fact that the hydrogen is produced with natural gas when more than the half of the Belgian electricity is nuclear. Contrarily to the sugar cane based E85, the B100 (RME) production is almost greenhouse neutral. Indeed, the benefit of the $\mathrm{CO}_{2}$ uptake from the air during the rape production is balanced by the effect of the intensive agricultural practices.

Another interesting finding of this study is the low climate impact of $\mathrm{CNG}$ vehicles. In fact, the natural gas production pollutes less than the conventional fossil fuels. Moreover, latest CNG vehicles (Euro 5) e.g. the 'Passat Estate EcoFuel 'can be more interesting than comparable hybrid of FCEV vehicles. However, the benefit of fuel saving of hybrid cars (lower TTW impact) compared to ICE vehicles is clearly identified in figure 2 . The relatively higher greenhouse effect of the LPG car can be explained by the fact that the LPG is modeled with propane/butane combined with a liquefaction process. The use of flare gas to produce LPG would reduce this impact.

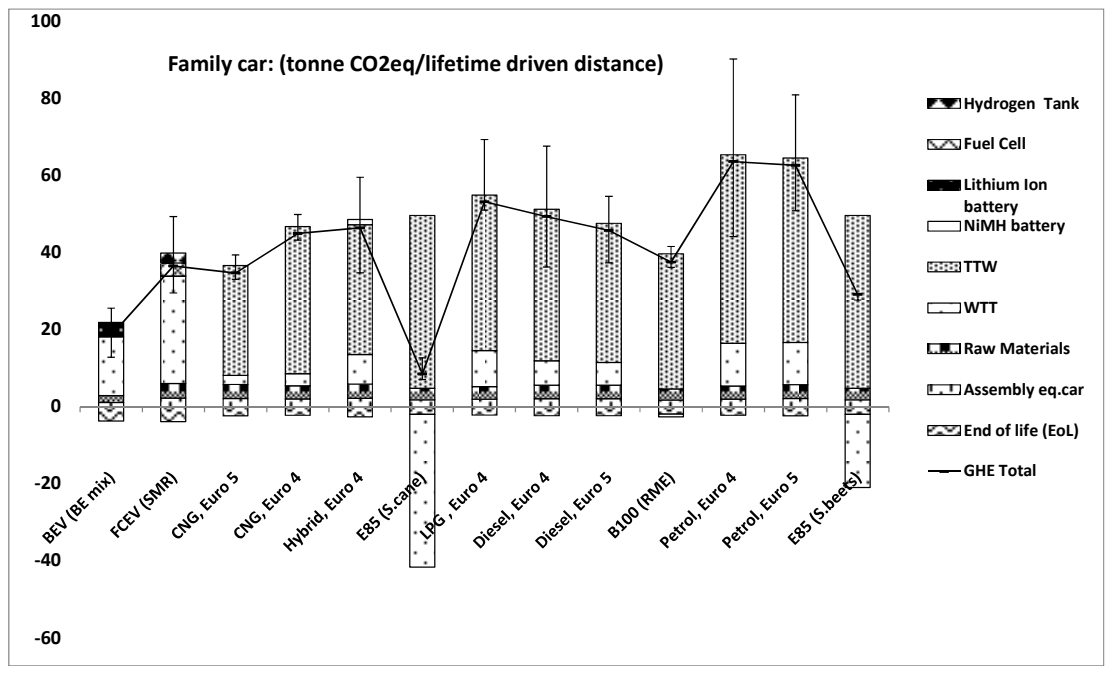

Figure 2: Comparative climate impact of different vehicle technology.

In order to have a deeper understanding of the results of this study, the LCA model has been run 1000 times with different values chosen randomly between the minimum and the maximum of all parameters modelled as a range. Thanks to this approach, the effect of the simultaneous variation of the vehicle weight, the energy consumption and the emissions has been assessed. For example, one can notice in figure 2 that the considered $\mathrm{BEV}$ powered with the Belgian electricity is not only better than the other fossil fuel vehicles in average but also better than the smallest fossil fuels vehicles of its segment. Thanks to this iterative approach, the overlaps between the different technologies are identified Unlike the case of climate impact, Petrol and Diesel vehicles appear to be more interesting than biofuel vehicles when dealing with the acidification impact 
(Figure 3). In the case of conventional and biofuel vehicles, it appears that the fuel production step is the main contributor. The RME vehicle has the highest impact in this category and pollutes two times more than diesel vehicles. This is due mainly to the high emissions of nitrogen based pollutants during the feedstock production and the higher NOx emission during the use phase of RME vehicles. Sugar cane and beet E85 vehicles have comparable acidification impact and score a bit lower than petrol vehicles. This is due to the feedstock production as well as the use of sulfuric acid before the fermentation of the cane or beet juice. Another interesting finding for this impact category is the result of the FCEV. In fact, the production of platinum contained in the fuel cell has a very big acidification impact but this impact is balanced by the recycling of the fuel cell. As a consequence, the FCEV will have for this impact the third best score after $\mathrm{CNG}$ and BEV. The benefit of switching from Petrol to Hybrid can also be seen in Figure 3. In fact, the low contribution of the WTT phase of the hybrid vehicle in comparison to the Petrol one is due to lower petrol consumption of hybrid car in comparison to conventional petrol car. However the higher contribution of the NiMH battery due to the nickel can be seen in the figure. Finally, it can be noticed that the acidification impact of Diesel vehicles are lower than the impact of petrol. This is due to the fact that the production of petrol emits more NOx than the production of Diesel. Diesel vehicles emit more NOx during the TTW phase but not more enough to balance the benefit of the lower NOx emission during the WTT.

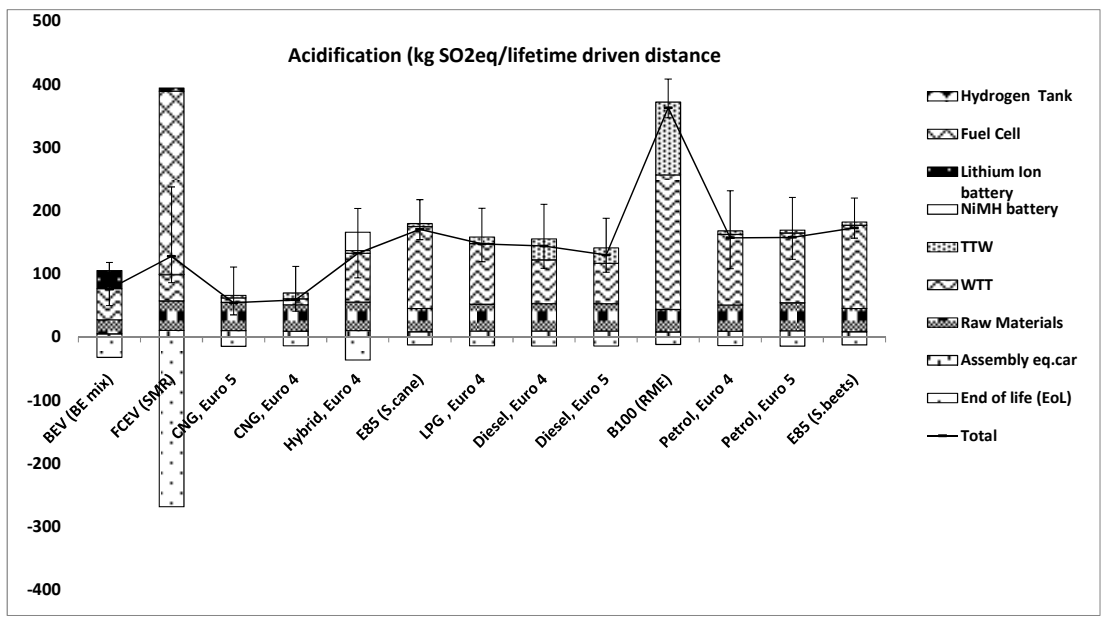

Figure 3: Acidification impact of different family car technologies.

Contrarily to the GHE, the E85 sugar cane technology has the highest impact for the respiratory effects (Figure 4). This is due mainly to the emission of CO, $\mathrm{CH}_{4}$ and $\mathrm{PM}$ during the field burning before the harvest (Moreira [24]). It is then followed by the RME vehicle. This high respiratory effect of the RME is due mainly to the emission of ammonia and nitrogen oxides which are directly linked 
to the use of nitrogen based mineral fertilizers. Additionally, the bio-diesel vehicle emits more nitrogen oxides than the corresponding diesel vehicle.

The lowest impact in this category goes to the $\mathrm{CNG}$ vehicle. The production of the natural gas has relatively low emission for all the considered pollutants in this category. This is also true for the direct emissions of the CNG vehicle. The $\mathrm{CNG}$ technology is followed by the BEV. The FCEV has a respiratory effect lower than the ICE vehicles but slightly higher than the BEV. Without the recycling credit the, the FCEV would have the worst score for this impact after the E85 and the RME vehicles.

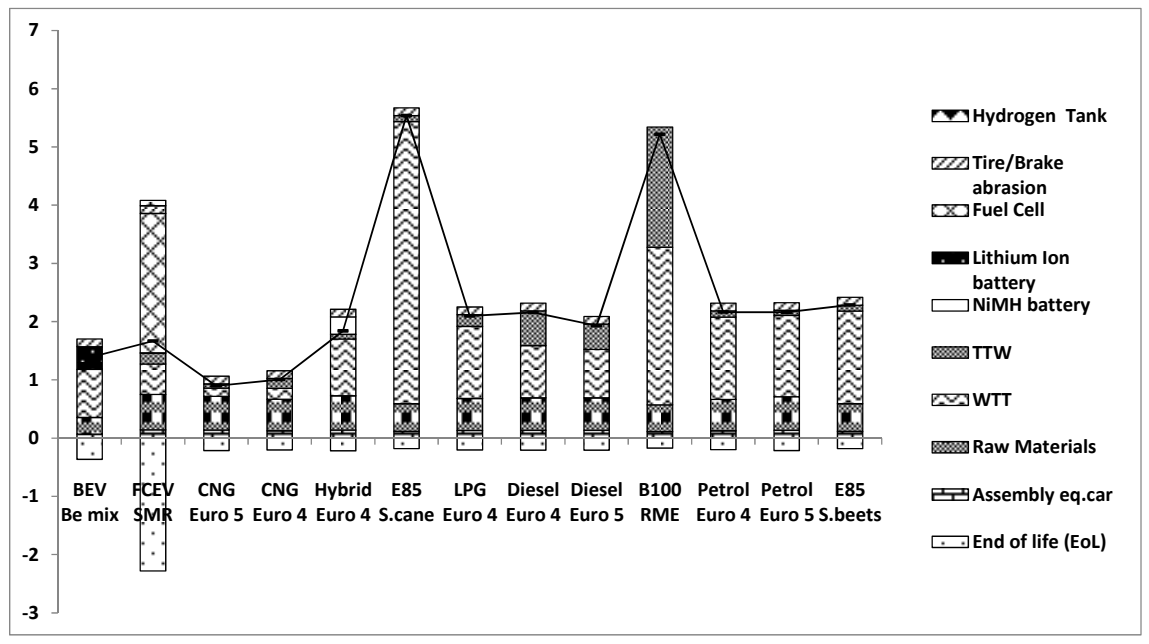

Figure 4: $\quad$ Respiratory effects of different family car technologies.

\section{Conclusion}

The results obtained in this paper are in line with references (Lane [25]; Bumham et al. [26], EUCAR, CONCAWE, JRC [13]; DaimlerChrysler [27], Nemry et al. [10]). It appears in this study that the engine technology, the type of fuel and the emission standards have strong influence on the LCA results. The environmental score of biofuels highly depends on the type of feedstock which is used to produce them. Thanks to new engine technologies and after treatment technologies, diesel vehicles become comparable to petrol vehicles when dealing human health (respiratory effects) impact. The CNG technology appears to be an interesting intermediate alternative before the full development of electric vehicles. On the methodological perspective, the LCA model used in this study allows to have a detailed environmental picture of all the type of vehicles of a fleet. Moreover, it allows drawing stronger conclusions because it includes all the individual cases of a fleet instead of an average situation. Finally, this approach is highly time saving because it allows including all the existing vehicles of a fleet in single LCA model instead of modelling them individually. 


\section{Acknowledgements}

This research has been made possible thanks to the support and funding of the Belgian Science Policy through the Science for a Sustainable Development (SSD) program. In this Framework the CLEVER 'Clean Vehicle Research: LCA and policy measure' project was carried out by Vrije Universiteit Brussel, Université Libre de Bruxelles; Vlaamse Instelling voor Technologisch Onderzoek (VITO) and RDC Environment.

\section{References}

[1] FCAI, segmentation criteria, http://www.fcai.com.au/sales/segmentationcriteria, accessed on October 12th, 2010.

[2] EURONCAP, http://www.euroncap.com/home.aspx, accessed on October 12 th, 2010.

[3] www.fisita.com, Visited on September 9, 2008.

[4] Reniers J., FEDERAUTO Magazine, August/September 2007.

[5] Boureima, F-S., Matheys, J., Wynen, V., Sergeant, N., Van Mierlo, J., Messagie, M., De Vos, M., De Caevel, B., Comparative LCA of electric, hybrid, LPG, diesel and gasoline vehicles in Belgian context, World Electric Vehicle Journal, Volume 3, ISBN-ISSN: 2032-6653, December 2009.

[6] FEBELAUTO, yearly report, 2006.

[7] FPS Economy, http://statbel.fgov.be/fr/statistiques/chiffres/circulation et transport/circulation/distances/index.jsp, accessed on July 22, 2010.

[8] Schweimer G. W, Levin M., Life Cycle Inventory for the Golf A4, 2000.

[9] Spielmann M., Bauer C., Dones R., Tuchschmid M., Ecoinvent report no 14: Transport services, Data V2.0, Villigen and Uster, December 2007.

[10] Nemry, F., Leduc, G., Mongelli, I., Uihlen, A., Environmental Improvement of Passenger cars (IMPRO-car), JRC-European Commission, 2008.

[11] Kudoh, Y., Nansai, K., Kondo, Y. Tahara, K., Life Cycle CO2 Emissions of FCEV, BEV and GV in Actual Use, the 23rd International Battery, Hybrid and Fuel Cell Electric Vehicle Symposium \& Exposition, Anaheim, USA, December 2nd-5th, 2007.

[12] Matheys, J., Timmermans, J., Van Mierlo, J., Meyer, S., Van Den Bossche, P., Comparison of the environmental impact of 5 electric vehicle battery technologies using LCA., International Journal of sustainable manufacturing, pp 318-329, ISBN-ISSN: 1742-7223, 2009.

[13] EUCAR, CONCAWE, JRC, Well-To-Wheels analysis of fuel automotive fuels and powertrains in the European context, Well-To-Wheels report, Version 2C, March 2007.

[14] Prieur A., Favreau D., Vinot S., Well-to-Tank technology pathways and carbon balance, Deliverable 4.3, Roads2hycom project, January 2009. 
[15] Frischknecht, R., Rebitzer, G., The ecoinvent database system: a comprehensive web-based LCA database, Journal of cleaner production, pp. 1337-1343, 13, 2005.

[16] Turcksin L., Macharis C., Lebeau K., Van Mierlo J., Bram S., De Ruyck J., Boureima F., Mertens L., Jossart J-M, Gorissen L., Pelkmans L., A multi-actor multi-criteria analysis to assess the stakeholder support for different biofuel options: the case of Belgium, Energy Policy, Volume: 39, $\mathrm{N}^{\circ}$ in volume: 1, pp: 200 - 214, ISBN-ISSN: 0301-4215.

[17] Schweimer G. W, Levin M., Life Cycle Inventory for the Golf A4, 2000.

[18] Timmermans J-M., Matheys J., Van Mierlo J., Lataire P., Environmental rating of vehicles with different fuels and drive trains: a univocal and applicable methodology, European journal of transport and infrastructure research, Vol. 6No. 4, pp. 313-334, 2006.

[19] OVAM, IBGE/BIM, OWD en RDC Environment, Validation of the recycling rates of end-of life vehicles, June 2008.

[20] International Iron and Steel Institute, Appendix 5 'Application of the IISI LCI data to Recycling Scenarios3', Life cycle inventory methodology report, 2002.

[21] IPCC Fourth Assessment Report, Climate Change 2007. The Physical Science Basis. http://www.ipcc.ch/ipccreports/ar4-wg1.htm

[22] Guinée J. B., Gorrée M., Heijungs R., Huppes G., Kleijn R., de Koning A., van Oers L., Wegener Sleeswijk A., Suh S., Udo de Haes H. A., de Bruijn H., van Duin R., Huijbregts M. A. J., Lindeijer E., Roorda A. A. H., Weidema B. P., Life cycle assessment; An operational guide to the ISO standards; Parts 1 and 2. Den Haag and Leiden, The Netherlands.

[23] Jolliet, O., Margni, M., Charles, R., Humbert, S., Payet, J., Rebitzer, G., Rosenbaum R., IMPACT 2002+: A New Life Cycle Impact Assessment Methodology, International Journal of Life Cycle Assessment, 8(6), pp. 324-330, 2003.

[24] Moreira, J.R., Sugarcane for energy-recent results and progress in Brazil; Energy for Sustainable Development, 5 (3), pp. 43-54, 2000.

[25] Lane B., Life cycle assessment of vehicle fuels and technologies, performed on behalf of the London borough of Camden, 69p., London, March 2006.

[26] Bumham A., Wang M., Wu Y., Development and application of GREET 2.7-The transportation vehicle-cycle model, Argonne national laboratory, 2006.

[27] DaimlerChrysler AG, Mercedes Car Group, Environmental Certificate Mercedes-Benz C-Class, Munich, 2006. 